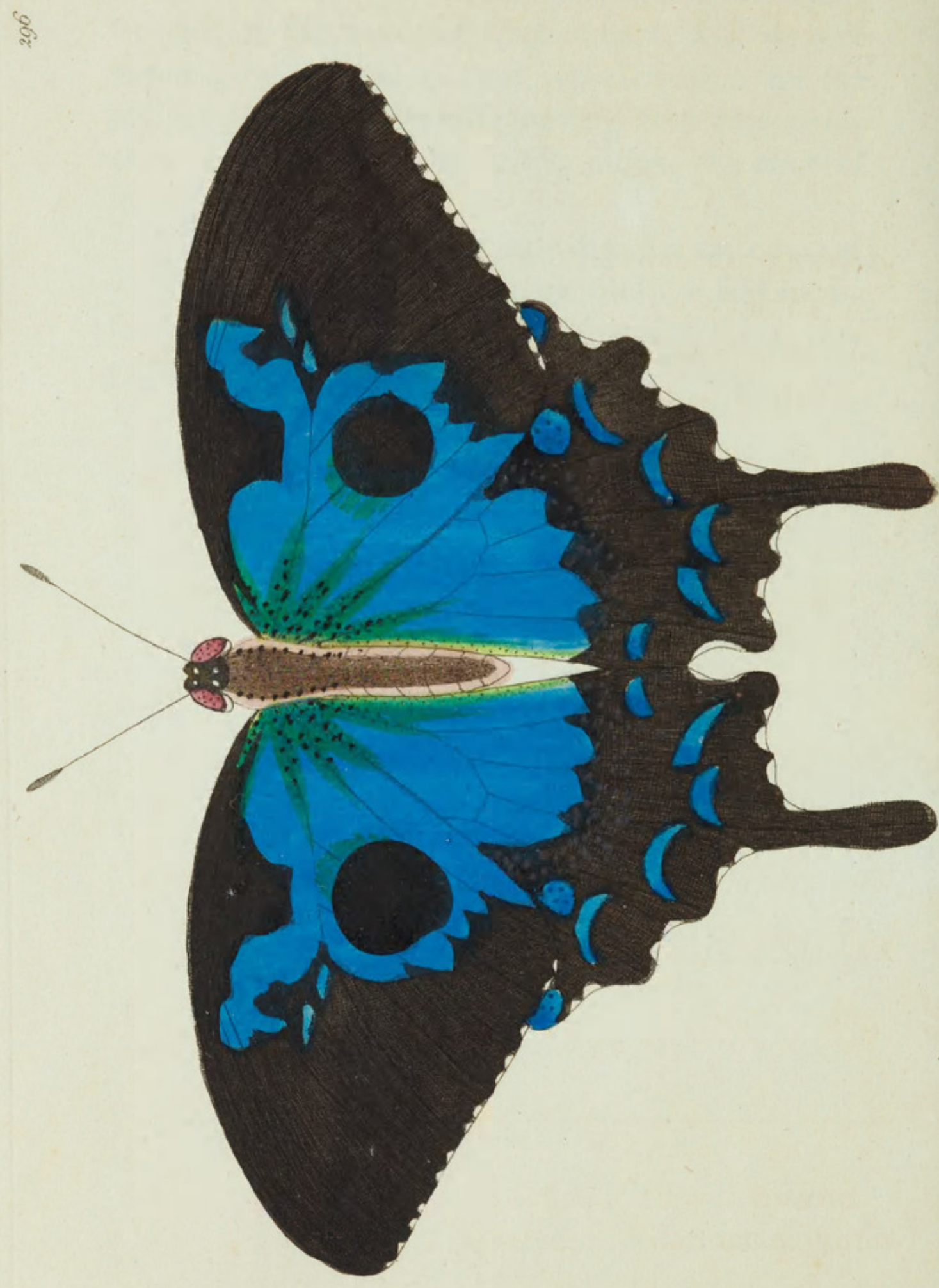




\section{PAPILIO DIOMEDES?}

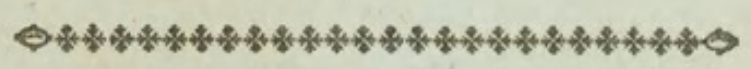

CHARACTER GENERICUS.

Antenna apicem verfus craffiores, fæpius clavatocapitatæ.

Ala fedentis erectæ furfumque conniventes, (volatu diurno).

$$
\text { Lin. Syft. Nat. p. } 744 \text {. }
$$

CHARACTER SPECIFICUS, ËC.

PAPILIO caudatus niger, alarum difco inæqualiter cæruleo-radiato, macula nigra rotundata ; pofterioribus lunulis marginalibus cæruleis。

An Var. P. Ulyffis?

Papilio DIOMEDES.

Cram. inf. t. I22. A.

\section{Pap. DIOMEDES ? ? ?}

$$
\begin{aligned}
& \text { Lin. Syft. Nat. p. } 749 . \\
& \text { Lin. Syft. Nat. Gmel. p. } 2236 .
\end{aligned}
$$

Indiam incolit pulcherrimus hic Papilio, magnitudine naturali in tabula depictus. 



\section{DIO MEDES?}

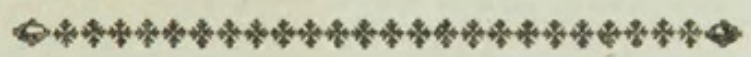

\section{GENERIC CHARACTER.}

Antennce thickening towards the upper part and generally terminating in a knob.

Wings (when fitting) erect and meeting upwards. (Flight diurnal.)

\section{SPECIFIC CHARACTER.}

Caudated black BUTTERFLY, with the difc of the wings unequally radiated with blue, with a round fpot of black: the lower wings marked by a row of blue crefcents round the margin.

This moft beautiful Infect is a native of India, and is reprefented on the plate in its natural fize. 


\section{$2 \mathrm{BHL}$ Biodiversity Heritage Library}

Shaw, George. 1797. "Diomedes, Papilio diomedes [PI. 296]." The Naturalist's Miscellany 8(XCV), https://doi.org/10.5962/p.310839.

View This Item Online: https://www.biodiversitylibrary.org/item/276320

DOI: https://doi.org/10.5962/p.310839

Permalink: https://www.biodiversitylibrary.org/partpdf/310839

\section{Holding Institution}

Museums Victoria

\section{Sponsored by}

Atlas of Living Australia

\section{Copyright \& Reuse}

Copyright Status: Public domain. The BHL considers that this work is no longer under copyright protection.

This document was created from content at the Biodiversity Heritage Library, the world's largest open access digital library for biodiversity literature and archives. Visit BHL at https://www.biodiversitylibrary.org. 